\title{
Procesné lehoty ako prostriedok odstránenia priet’ahov v konaní, v kontexte práva na spravodlivé súdne konanie'
}

Júlia Ondrová *

DOI: https://doi.org/10.24040/sap.2021.8.2-3.160-174

\begin{abstract}
Abstrakt:
ONDROVÁ, Júlia: Procesné lehoty ako prostriedok odstránenia priet'ahov v konaní, v kontexte práva na spravodlivé súdne konanie. V zmysle článku 1 ods. 1 a v spojení s článkom 2 ods. 2 Ústavy SR je Slovenská republika zvrchovaný, demokratický a právny štát, v ktorom štátne orgány môžu konat' iba na základe ústavy, v jej medziach a v rozsahu a spôsobom, ktorý ustanoví zákon. Uvedené ústavné znenie znamená vyjadrenie základných princípov právneho štátu. Pokial’ však ide o právny štát, jeho kvalifikačným znakom je aj možnost' domáhat' sa zákonom ustanoveným postupom svojho práva na nezávislom a nestrannom súde, pričom podl’a článku 48 ods. 2 Ústavy SR má každý právo, aby sa jeho vec prerokovala bez zbytočných priet’ahov. Absenciu zákonných lehôt trvania procesných úkonov súdu či presného vymedzenia dížky trvania súdneho konania do vydania meritórneho rozhodnutia možno síce hodnotit' ako legislatívny nedostatok, avšak s prihliadnutím na osobitosti každého prípadu by presné stanovenie dížky konania nebolo právne správne. Právnym riešením môže byt' stanovenie tzv. odporúčaných zákonných lehôt, v ktorom by súdne konanie malo skončit'.
\end{abstract}

Kl’účové slová:

právo na súdne konanie, rýchlost' konania, ochrana práv, procesné lehoty

\section{Procedural Deadlines as Means of Removing Delays in Proceedings Within the Context of Law Regarding the Right to Just Trial}

\begin{abstract}
:
ONDROVÁ, Júlia: Procedural Deadlines as Means of Removing Delays in Proceedings given by Law to the Right to Just Trial. Ad effectum Article 1 paragraph 1 in connection with Article 2 paragraph 2 of the Slovak Republic Constitution, the Slovak Republic is the sovereign, democratic and lawful state where the state bodies can only act based on the Constitution within its measures, range and ways declared by law. According to the given constitution declaration the basic lawful state principles are stated. But having in mind the lawful state, its qualified indication creates an opportunity as well to claim one`s right to independent and impartial trial
\end{abstract}

1 Vedecká štúdia je výsledkom riešenia projektu „Hodnoty v práve“, ktorý je financovaný Vedeckou grantovou agentúrou Ministerstva školstva, vedy, výskumu a športu Slovenskej republiky a Slovenskej akadémie vied (projekt č. 1/0619/21).

* JUDr. Júlia Ondrová, PhD., Univerzita Mateja Bela v Banskej Bystrici, Právnická fakulta, Katedra ústavného práva a teórie práva, odborná asistentka, julia.ondrova@umb.sk 


\begin{abstract}
as it is declared by law. By Article 48 paragraph 2 of the SR Constitution, everybody has the right to advance his/her case without any delays. The absence of the legalprocedural-acts duration of the court-time-stretch or the exact delimitation of the court procedure up to the meritorious decision release can be judged as the legislative default. However, considering the specification of every case, the exact stated length of proceeding would not be correct. The legal solution might be to state the so-called recommended time limits during which the court action should be completed.
\end{abstract}

\title{
Keywords:
}

the right to just trial, fast procedure, protection of rights, procedural time-limits

\section{Úvod}

Realizácia subjektívnych práv jednotlivcov ako aj poskytnutie ochrany porušených, porušovaných či len ohrozených práv subjektov práva sa spája najmä s orgánmi súdnej moci a ich činnostou. Každý zo subjektov práva, ktorý iniciuje súdne konanie má osobitný záujem na tom, aby ochrana, o ktorú žiada, bola účinná. Pod pojmom ,účinný““ je možné vnímat' vel'ké množstvo pojmov, od správneho a spravodlivého rozhodnutia, až po rýchlost' konania. V kontexte nižšie uvedeného obsahu bude priblížené najmä časové hl'adisko súdnych konaní a potreba rýchlosti konania pri dodržaní zásady zákonnosti. S prihliadnutím na aplikačnú prax ako aj právnu teóriu možno konštatovat', že len súdne konanie, $\mathrm{v}$ ktorom je $\mathrm{v}$ čo najkratšom čase vydané meritórne rozhodnutie možno nazývat' ako účinné čo do ochrany subjektívnych práv a zároveň aj ako spravodlivé, v kontexte právnych predpisov a ustálenej judikatúry. Otázkou právneho posúdenia však ostáva vymedzenie dížky súdneho konania, ktorú je možné ešte považovat' za primeranú.

\section{Právo na spravodlivý proces a otázka primeranosti dížky konania}

Právo na spravodlivý proces je jedným zo základných prvkov právneho štátu. ${ }^{2}$ Ochrana porušovaných, porušených alebo len ohrozených práv musí podla právnej teórie splńat' dva základné atribúty, a to spravodlivost' a účinnost'. Pojem účinnost' je možné stotožnit's princípom procesnej ekonómie, ktorú je v kontexte súdneho konania potrebné vnímat' ako nevyhnutnú potrebu konat' rýchlo a bez zbytočnej preformalizovanej ochrany. ${ }^{3}$ Druhým termínom je spravodlivost'. S prihliadnutím na široký obsah spravodlivosti a v kontexte súdneho konania, je pri najväčšej miere zovšeobecnenia možné spravodlivost' vnímat' ako poskytovanie ochrany práv na širokej spoločenskej úrovni.

Pokial' ide o účinnost' súdnej ochrany je nutné zdôraznit', že z právneho hl'adiska ide o nevyhnutný predpoklad legitimity zákazu svojpomoci pri obrane vlastných záujmov. Účinná súdna ochrana je z faktického hl’adiska aj dôležitou podmienkou absencie motivácie využívat' rôzne svojpomocné nástroje ochrany bez ohl'adu na ich súlad s právnym poriadkom. ${ }^{4}$

2 K tomu pozri: HAASE, K. Die Anforderungen an ein faires Gerichtsverfahren auf europäischer Ebene. Driesen : Dr. H. H. Verlag., 2006. 511 s.

3 ŠTEVČEK, M. a kol. Civilný sporový poriadok. Komentár. Praha : C. H. Beck, 2016. s. 26.

4 PROCHÁZKA, R. L’ud a sudcovia v konštitučnej demokracii. Plzeň : Aleš Čenek, 2011. s. 67. 
Na podklade prípadov aplikačnej praxe možno vyvodit' záver, že len súdne konanie, ktoré je dostatočne rýchle, resp. $\mathrm{v}$ ktorom dochádza $\mathrm{k}$ minimalizovaniu prietahov, za súčasného dodržania princípu zákonnosti, je možné označit' pojmom účinné a spravodlivé.

Konštatované je odvoditel'né zo záujmu subjektu, ktorý sa ochrany svojich práv domáha na súde. Ak žiadaná ochrana práv nastane príliš neskoro, aj keby bola v prospech subjektu, ktorý konanie inicioval, stane sa bezpredmetnou. Dôležité sú najmä konania, kde môže dôjst' k trvalému narušeniu medzil'udských vzt’ahov, napríklad rodinnoprávnych. ${ }^{5}$

Vyššie uvedené princípy spravodlivosti a rýchlosti konania ${ }^{6}$ sú vyjadrené v mnohých právnych dokumentoch. V právnom poriadku Slovenskej republiky ide najmä o články 46 a 48 ústavného zákona č. 460/1992 Zb. Ústava Slovenskej republiky v platnom znení (d'alej v texte ako „Ústava Slovenskej republiky“). ${ }^{7}$

Z oblasti súkromného práva možno spomenút články 2 a 17 zákona č. 160/2015 Z. z. Civilného sporového poriadku v platnom znení (d’alej v texte ako „CSP“), resp. článok 12 zákona č. 161/2015 Z. z. Civilného mimosporového poriadku v platnom znení, ${ }^{8}$ podla ktorého v konaní súd postupuje tak, aby vec bola čo najrýchlejšie prejednaná, rozhodnutá a predchádza zbytočným priet’ahom.

Verejné právo spája princípy rýchlosti a spravodlivosti konania najmä s právom trestným, ako napríklad $\S 2$ ods. 7 zákona č. 301/2005 Z. z. Trestný poriadok v platnom znení. ${ }^{9}$

Ústavný súd Slovenskej republiky vo svojej judikatúre opakovane ${ }^{10}$ odkazuje na

5 K tomu pozri: ŠTEVČEK, M. - PAVELKOVÁ, B. - CIRÁK, J. Rodinné právo. Šamorín : Heuréka, 2008. $216 \mathrm{~s}$.

6 K tomu pozri: ONDROVÁ, J. Právo na spravodlivý proces v rozhodovacej činnosti Ústavného súdu Slovenskej republiky a Európskeho súdu pre l'udské práva. Banská Bystrica : Belianum, Vydavatel'stvo Univerzity Mateja Bela v Banskej Bystrici. 2018. 143 s.

$7 \quad$ K rozdielnosti právnej úpravy obsiahnutej v Ústave Slovenskej republiky a Listine základných práv a slobôd pozri: CIBULKA, L. Kontexty Ústavy SR a Listiny základných práv a slobôd. In Deset let Listiny základných prav a svobod v právním řádu České republiky a Slovenské republiky. Brno : Masarykova univerzita Brno. 2001. s. 78.; K tomu pozri: WAGNEROVÁ, E. a kol. Listina základnich práv a svobod. Komentár̆. Praha : Wolters Kluwer ČR, a. s. 2012, 906 s.

8 K tomu pozri: SMYČKOVÁ, R. a kol. Civilný mimosporový poriadok. Komentár. 1. vydanie. Bratislava. C. H. Beck, 2017, 1112 s.

9 V súvislosti so zásadami rýchlosti a spravodlivosti konania pozri aj predvídatel'nost' súdnych rozhodnutí napríklad: MAĎAR, M. Predvídatel'nost' súdnych rozhodnutí ako súčast' práva na spravodlivý proces. In Banskobystrické dni práva : zbornik z 2. ročnika medzinárodnej vedeckej konferencie na tému „Kvalita normotvornej a aplikačnej stránky zákonnosti ako determinant právneho štátu”, 23.-24. november 2016. Banská Bystrica : Vydavatel'stvo Univerzity Mateja Bela - Belianum, 2017. s. 134-145. K tomu pozri: HARRIS, D.J. a kol. Law of the European Convention on Human Rights. Third Edition. Oxford University Press, 2014. s. 442; SVÁK, J. Právo na súdnu a inú právnu ochranu. In SVÁK, J. - CIBULKA, L. Ústavné právo Slovenskej republiky, Osobitná čast'. 5. Aktualizované vydanie. Bratislava : Eurokódex s.r.o. a Paneurópska vysoká škola, 2013. s. 651. Podrobná analýza trestnej vetvy je riešená v HENZELIN. M. - RORDORF, H. When does the length of criminal proceedings become unreasonable according to the European Court of Human Rights? In New Journal of European Criminal Law, 2014, Vol. 5, Issue 1, s.79-109. [2020-06-30]. Dostupné na internete: https://www.lalive.law/data/publications/NJECL_05_01_0078.pdf

10 K tomu pozri: Uznesenie Ústavného súdu Slovenskej republiky sp. zn. II. ÚS 534/2011 zo dňa 23.11.2011. 
svoj právny názor uvedený už v náleze sp. zn. II. ÚS 26/95 zo dňa 25.10.1995, v ktorom zdôraznil, že účelom práva na prerokovanie veci bez zbytočných prietahov je odstránenie stavu právnej neistoty, v ktorej sa nachádza osoba domáhajúca sa rozhodnutia štátneho orgánu. Stav právnej neistoty osoby sa však len samotným prerokovaním veci neodstráni. Právna istota, ako základný princíp ${ }^{11}$ právneho štátu ${ }^{12}$ osobitne v jeho materiálnom vnímaní, ${ }^{13}$ sa vytvára až právoplatným rozhodnutím vo veci samej.

V súvislosti so zmieňovaným ústavným právom na prerokovanie veci bez zbytočných priet’ahov má osobitnú dôležitost' aj judikatúra Európskeho súdu pre l'udské práva a Dohovor o ochrane l’udských práv a základných slobôd (d’alej v texte ako „Dohovor"). $V$ rámci Dohovoru ${ }^{14}$ sú princípy rýchlosti a spravodlivosti konania premietnuté do článku 6 ods. 1 Dohovoru. ${ }^{15}$ Súčasne, znenie článku 6 ods. 1 Dohovoru ${ }^{16}$ zaväzuje zmluvné štáty $\mathrm{k}$ tomu, aby svoje právne systémy usporiadali spôsobom umožňujúcim vnútroštátnym súdom plnit' všetky požiadavky rôzneho druhu, ktoré sú zo strany fyzických osôb, právnických osôb a štátu na orgány súdnej moci kladené.

Pokial' ide o priet'ahy v konaní, podla právneho názoru Najvyššieho súdu Slovenskej republiky vyjadrenom v uznesení sp. zn. 1 Cdo 107/2009 zo dňa 28. 07. 2010, ide o protiprávny stav, a to v každom okamihu, pretože nimi vždy dochádza $\mathrm{k}$ rovnakému porušovaniu práva účastníka konania, a síce práva na prejednanie veci bez zbytočných priet’ahov. Ústavný súd Slovenskej republiky v uznesení sp. zn. II. ÚS 650/2015 zo dňa 06.10. 2015 definoval priet’ahy v konaní ako autonómny pojem, ktorý treba vykladat' a aplikovat' predovšetkým materiálne. V súlade s uvedeným, Ústavný súd Slovenskej republiky vo svojej rozhodovacej činnosti vytvoril rozdiel medzi priet’ahmi v súdnom konaní s prívlastkom „štandardné“ a priet’ahmi označovanými ako „kvalifikované“. Priet’ahom v konaní s prívlastkom štandardný poskytuje Ústavný súd Slovenskej republiky ochranu podl’a čl. 48 ods. 2 Ústavy Slovenskej republiky. Na druhej strane, charakteristickým znakom kvalifikovaného prietahu v konaní je vždy odmietnutie spravodlivosti. ${ }^{17}$

11 Právny princíp je štandard, ktorý sa má zachovávat', a to z dôvodu, že si to vyžaduje spravodlivost', slušnost' alebo morálka. - K tomu pozri: DWORKIN, R. Když se práva berou vážně. Praha : Oikoymenh, 2001. s. 44.

12 K právnemu štátu pozri: PRUSÁK, J. Teória práva. Bratislava : Právnická fakulta UK, 2001. s. 166.

13 V súvislosti s materiálnym právnym štátom sú to práve ústavy štátov, ktoré určujú pravidlá politických rozhodnutí a základné princípy, podl'a ktorých dochádza k rozumnému usporiadaniu spoločnosti. - K tomu pozri: VORLÄNDER, H. Die Verfassung. Idee und Geschichte. München : C. H. BECK, 2009. s. 9.

14 K tomu pozri: ONDROVÁ, J. Postavenie Európskeho dohovoru o ochrane l’udských práv a základných slobôd v právnom poriadku Slovenskej republiky. In Notitiae Novae Facultatis Iuridicae Universitatis Matthiae Belii Neosolii. Banská Bystrica : Vydavatel'stvo Univerzity Mateja Bela - Belianum, 2018. s. 154-162.; KMEC, J. a kol. Evropská úmluva o lidských právech. Komentář. 1. vydání. Praha : C. H. Beck, 2012. s. 542.

15 CHOVANEC, J. - ZACHOVÁ, A. Ústavné garancie základných l'udských a občianskych práv a slobôd. Bratislava : Procom, s. r. o., 2004, s. 125.

16 K Dohovoru pozri: RENZIKOWSKI, J. Die EMRK im Privat-Straf- und Öffentlichen Recht, Grundlagen einer europäischen Rechtskultur. Zürich : Schulthess Verlag, 2004, 255 s.

17 DRGONEC, J. Ústava Slovenskej republiky - Velký komentár. Teória a prax. Bratislava : C. H. Beck, 2015. s. 924. 
Pred vyslovením záveru, že v konaní vznikli priet’ahy je nutné posúdit' celé konanie. Nečinnost' všeobecného súdu, ktorá nastala $\mathrm{v}$ dôsledku právoplatného uznesenia o prerušení konania, ako prekážky v postupe súdu vytvorenej zákonom ustanoveným postupom, však nie je možné posudzovat' ako zbytočné prietahy v súdnom konaní. ${ }^{18}$ A contrario, nedostatočné personálne obsadenie súdu a nadmerné množstvo vecí by vzniknuté priet’ahy v konaní mohli len dočasne ospravedlnit', a to len v prípade, ak sa na ten účel prijali včas adekvátne opatrenia. ${ }^{19}$ Systémové nedostatky v oblasti výkonu spravodlivosti preto nemožno pripisovat' na t’archu účastníkov súdneho konania, resp. nimi oslabit' mieru ochrany ich práv zaručených článkom 48 ods. 2 Ústavy SR. ${ }^{20}$ Podl'a nálezu Ústavného súdu Slovenskej republiky sp. zn. III. ÚS 47/2017 zo dňa 25.04.201721 porušenie práva na prerokovanie veci bez zbytočných priet'ahov môže vzniknút' nielen nečinnost'ou súdu, ale aj neefektívnou činnost'ou súdu.

V súvislosti s posúdením právnej otázky, či v konaní, v ktorom sú prítomné zbytočné priet’ahy, došlo k odopretiu spravodlivosti, možno vychádzat' z argumentačnej línie uvedenej v náleze Ústavného súdu Slovenskej republiky sp. zn. II. ÚS 8/01 zo dňa 18.06.2001, podla ktorej nekonanie súdu s rizikom dopustenia sa priet'ahov v konaní môže znamenat' porušenie základného práva navrhovatel’a upraveného v čl. 48 ods. 2 Ústavy SR, ale spravidla nie odmietnutie spravodlivosti, ktoré by malo za následok porušenie základného práva upraveného v čl. 46 ods. 1 ústavy. Ústavný súd Slovenskej republiky v tomto náleze rozlišuje dve úrovne následkov nekonania súdu: a) porušenie práva na súdnu ochranu podl'a čl. 46 ods. 1 Ústavy SR a b) porušenie práva na prerokovanie veci bez zbytočných priet’ahov podl'a čl. 48 ods. 2 Ústavy SR. Konštatovanie zbytočných priet’ahov je podl’a Ústavného súdu Slovenskej republiky nevyhnutnou, avšak väčšinou nie dostačujúcou podmienkou pre závažnejší následok odopretia spravodlivosti zapríčinený zo strany súdu jeho nekonaním.

S uvedeným názorom Ústavného súdu Slovenskej republiky sa je možné stotožnit' len čiastočne, a to z dôvodu, že ak sa konanie vyznačuje priet’ahmi v konaní, ktoré trvajú dlhodobo, nie je potom prípustné nazývat' konanie ako spravodlivé, pretože dochádza k odopretiu rýchlej ochrany práv, ktorej sa určitý subjekt v rámci právomoci orgánu verejnej moci domáha.

\section{Posúdenie primeranosti dížky konania a návrhy de lege ferenda}

Prípadom súdnej praxe, ktorý určite nie je možné nazvat' ako rýchly, účinný či spravodlivý predstavuje súdne konanie Jennes v. Jennes, prebiehajúce v rokoch 1798 až 1915. Išlo o skutočný prípad p. Jennesa, ktorý bol v tom čase najbohatší muž v Británii. Zomrel však bez akýchkol'vek potomkov a závet, ktorý sa našiel v jeho vrecku bol síce zapečatený ale nie podpísaný. Spor sa týkal prejavu poslednej vôle

18 Nález Ústavného súdu Slovenskej republiky sp. zn. I. ÚS 697/2013 zo dňa 19.03.2014.

19 Nález Ústavného súdu Slovenskej republiky sp. zn. II. ÚS 498/2013 zo dňa 11.06.2014 mutandi mutandis: Nález Ústavného súdu Slovenskej republiky sp. zn. III. ÚS 139/2015 zo dňa 16.06.2015.

20 K tomu pozri: Nález Ústavného súdu Slovenskej republiky sp. zn. IV. ÚS 471/2012 zo dňa 07.05.2013.

21 K tomu pozri: Nález Ústavného súdu Slovenskej republiky sp. zn. I. ÚS 65/2016 zo dňa 08.06.2016. 
poručitel'a a skončil po 117 rokoch, kedy už súdne poplatky strovili celý majetok, ktorý bol predmetom rozhodovacej činnosti. ${ }^{22}$

Z dnešného pohl'adu je doba konania uvedeného prípadu absolútne neprípustná. Pre objektívne posúdenie dížky konania je však dôležité správne určenie momentu začatia plynutia „primeranej“ dížky konania. Štrasburské orgány ochrany práva preto vytvorili kritériá pre posudzovanie adekvátnej rýchlosti súdneho konania, pričom vždy zohl'adňujú aj individuálnost' predmetného prípadu. ${ }^{23}$ Európsky súd pre l'udské práva opakovane zdôrazňuje, že primeranost' dížky konania je rozličná v civilných veciach a iná v trestných veciach. Vo veci Ersin Ceyhan ${ }^{24} \mathrm{~s}$ odkazom na staršie prípady ${ }^{25}$ uviedol, že v občianskoprávnych veciach plynie lehota odo dňa začatia konania, ktoré spravidla začína dňom podania žaloby či návrhu na príslušný súd, ktorým je zvyčajne súd prvej inštancie. Začiatok lehoty v trestných veciach sa oficiálne spája s oznámením doručeným príslušným orgánom, ktoré obsahuje tvrdenie, že niekto spáchal trestný čin. Koniec rozhodného obdobia sa spája s úplným skončením predmetnej veci, bez ohl'adu na to, na ktorom stupni zo sústavy orgánov súdnej moci konanie skončí.

Problémom aplikačnej praxe je práve skutočnost', že čas na konanie bez zbytočných priet'ahov spravidla nemožno vyjadrit' numericky. Spravidla neexistuje žiadna časová hranica, ktorej uplynutím by bolo možné súdne konanie označit’ ako konanie s priet'ahmi. ${ }^{26}$ Výnimkou z tohto pravidla sú konania, v ktorých ústava alebo zákon ustanovuje lehotu na rozhodnutie. Príkladom je vydanie neodkladného opatrenia podla $\S 328$ ods. 2 CSP, a to v lehote 30 dní, alebo 24 hodín odo dňa doručenia návrhu.

Pokial ide o možnost' domáhat' sa ochrany svojich práv a namietat' porušenie princípu spravodlivosti súdneho konania v súvislosti s priet’ahmi v konaní pred Európskym súdnym dvorom pre l’udské práva, tento pomerne často opakuje, že primeranost' dížky súdneho konania sa musí hodnotit' vo svetle okolností prípadu a s odkazom na kritériá, akými sú zložitost' prípadu, správanie st'ažovatel'a a relevantných orgánov, a to, čo je pre st’ažovatel’a v prebiehajúcom konaní podstatné. ${ }^{27}$

Európsky súd pre l’udské práva najčastejšie pre hodnotenie zložitosti veci používa tri stupne, t. j. 1) vec, ktorá nie je zložitá, 2) vec, ktorá vykazuje určitú mieru zložitosti a 3) vec, ktorá je vel'mi zložitá alebo je zložitá výnimočným spôsobom. ${ }^{28}$ Európsky súd pre l'udské práva používa slová ako „urýchlene”, „výnimočná starostlivost' pri zabezpečovaní vedenia konania” a „osobitná rýchlost”" na popísanie požiadavky

22 BRÖSTL, A. Na konci je súd. Bratislava : Kalligram, 2015. s. 100.

23 SVÁK, J. a kol. Advokát pred európskymi súdmi. Bratislava : Poradca podnikatela, spol. s. r. o., 2004. s. 43.

24 Rozhodnutie Európskeho súdu pre l’udské práva vo veci Ersin Ceyhan no. 2013/695, zo dňa 09.01.2014.

25 Rozhodnutie Európskeho súdu pre l'udské práva vo veci Zimmerman a Steiner vs. Švajčiarsko no. 8737/79, zo dňa 13.07.1983; Rozhodnutie Európskeho súdu pre l’udské práva vo veci Deweer vs. Belgicko no. 6903/75, zo dňa 27.02.1980.

26 Nález Ústavného súdu Slovenskej republiky sp. zn. II. ÚS 64/99 zo dňa 13.07.1999.

27 Rozhodnutie Európskeho súdu pre l’udské práva vo veci Sürmeli vs. Nemecko no. 75529/01, zo dňa 08.06.2006; Rozhodnutie Európskeho súdu pre l’udské práva vo veci Lupeni Greek Catholic Parish and Others vs. Rumunsko no. 76943/11, zo dňa 29.11.2016.

28 Bližšie: KMEC, J. a kol. Evropská úmluva o lidských právech. Komentár. 1. vydání. Praha : C. H. Beck, 2012, s. 704-706. 
včasnosti. ${ }^{29}$ Prípadmi osobitnej rýchlosti ${ }^{30}$ sú najmä prípady starostlivosti ${ }^{31}$ o deti, ${ }^{32}$ osobného statusu ${ }^{33}$ a spôsobilosti, alebo pracovné spory.

Pri posudzovaní otázky či v súdnom konaní došlo k zbytočným priet’ahom Ústavný súd Slovenskej republiky v náleze sp. zn. II. ÚS 268/2019 zo dňa 23.01.2020 uviedol ako rozhodné kritéria: 1) zložitost' veci, 2) správanie účastníkov súdneho konania a 3) postup samotného súdu.

Skutkovými okolnost’ami, na základe ktorých je možné vec považovat' určitým stupňom za zložitú, môžu byt' podla právneho názoru Európskeho súdu pre l’udské práva napr. zložité majetkové vysporiadanie $\mathrm{v}$ konaní ${ }^{34}$ alebo počet obvinených a rozsah trestnej činnosti, z ktorej sú obvinení. ${ }^{35}$ Aplikačná prax ukazuje, že procesná zložitost' veci je často zapríčinená existenciou väčšieho počtu účastníkov konania alebo potrebou zaobstarania dôkazov rôzneho druhu.

Právne či skutkovo náročný spor však tiež nesmie trvat’ neprimerane dlhú dobu. Časový horizont toho, kedy sa účastníkovi konania dostáva konečného rozhodnutia vo veci predstavuje neoddelitel'nú súčast' meradiel celkovej spravodlivosti podla čl. 46 ods. 1 Ústavy SR. Čím je tento časový horizont dlhší, tým viac sa rozostrujú kontúry spravodlivosti ako v očiach dotknutých účastníkov konania, tak aj vo všeobecnom vnímaní verejnosti a verejnej mienky. ${ }^{36}$

V súvislosti s konaním, ktoré bolo právoplatne skončené, Ústavný súd Slovenskej republiky v náleze sp. zn. II. ÚS 510/2014 zo dňa 11.06.2015 uviedol, že ak porušenie základného práva na prerokovanie veci bez zbytočných prietahov podl’a čl. 48 ods. 2 Ústavy SR prekročí takú intenzitu, že to signalizuje zo strany príslušného všeobecného súdu odmietnutie možnosti domáhat' sa svojho práva na nezávislom a nestrannom súde, ${ }^{37}$ tak možno urobit' záver o tom, že takýmto postupom súdu došlo, resp. dochádza aj k porušeniu základného práva na súdnu ochranu podla čl. 46 ods. 1 Ústavy SR.

Pokial' ide o kritérium správania sa účastníkov súdneho konania, článok 6 ods. 1 Dohovoru nevyžaduje od st’ažovatel’ov, aby aktívne spolupracovali so súdnymi or-

29 CHRISTOFFERSEN, J. Fair balance: proportionality, subsidiarity and primarity in tje European Convention on Human Rights. International studies in human rights, v.99. Koninklijke Brill NV : Leiden, 2009, s. 467.

30 Krozhodovacej činnosti Európskeho súdu pre l’udské práva pozri: KOENIG, M. Menschenrechte. Campus Verlag GmbH : Frankfurt, 2005. 168 s.

31 K požiadavke osobnej starostlivosti pozri: MARTIN, C. - RODRÍGEUZ-PINZÓN, D. BROWN, B. Human Rights of Older People. Universal and Regional Legal Perspectives. Springer Science+Bussiness Media: Dordrecht, 2015. s. 199-200.

32 Rozhodnutie Európskeho súdu pre l’udské práva vo veci Niederböster vs. Nemecko no. 39547/98, zo dňa 27.02.2003.

33 K tomu pozri: BÜHRER, T. Das Menschenwürdekonzept der Europäischen Menschenrechtskonvention. Duncker \& Humblot : Berlin, 2020.361 s.

34 K tomu pozri: Rozhodnutie Európskeho súdu pre l'udské práva vo veci Schmidtová vs. Česká republika no. 48568/99, zo dňa 22.07.2003.

$35 \mathrm{~K}$ tomu pozri: Rozhodnutie Európskeho súdu pre l'udské práva vo veci Nemeth vs. Česká republika no. 35888/02, zo dňa 20.09.2005.

36 Nález Ústavného súdu Slovenskej republiky sp. zn. I. ÚS 688/2014 zo dňa 04.02.2015.

37 SVÁK, J. Nezávislost' súdnictva a zodpovednost' sudcov. In Právny obzor. 1997. roč. 80, č. 5, s. 487-498. 
gánmi. Ústavný súd Slovenskej republiky v náleze sp. zn. II. ÚS 862/2015 zo dňa 17.03.2016 judikoval, že k predíženiu napadnutého konania prispel stažovatel' tým, že neposkytol súdu potrebnú súčinnost' pri zist'ovaní, či sú u neho splnené predpoklady na oslobodenie od platenia súdnych poplatkov. Podl'a názoru Ústavného súdu Slovenskej republiky z platných právnych predpisov síce vyplýva povinnost' účastníka konania prispiet' $k$ dosiahnutiu účelu konania, avšak nečinnost' účastníka konania súd nezbavuje povinnosti pokračovat' $\mathrm{v}$ konaní, a tak zabránit' zbytočným priet’ahom. Zároveň je pritom možné takú nečinnost' účastníka konania označit' za okolnost', ktorá vplýva na celkovú dížku konania negatívnym spôsobom.

Článok 6 ods. 1 Dohovoru rovnako neumožňuje zazlievat' účastníkom konania, že v celom rozsahu využívajú prostriedky, ktoré im priznáva vnútroštátny právny poriadok. A predsa takéto správanie predstavuje objektívnu skutočnost', ktorú nemožno pripísat' štátu, voči ktorému sa vedie konanie vo veci porušenia čl. 6 ods. 1 Dohovoru. ${ }^{38}$ Vnútroštátnym orgánom síce nie je možné pričítat' zodpovednost' za správanie účastníka konania, avšak skutočnost', že sa jedna zo strán uchyl’uje ku zdržiavacej taktike, ich nezbavuje povinnosti zabezpečit' skončenie konania v primeranej lehote. Európsky súd pre luudské práva zároveň dodáva, že od dotknutej osoby sa vyžaduje výlučne to, aby s dostatočnou starostlivost'ou postupovala pri vykonávaní procesných úkonov, aby sa neuchyl'ovala $\mathrm{k}$ zdržiavacej taktike a aby v prípade takej možnosti využila skrátenie konania, ktoré jej umožňujú vnútroštátne právne predpisy.

Správanie orgánov štátu posudzuje Európsky súd pre l’udské práva s osobitným dôrazom, pričom vychádza zo zásady, že ak konanie nebolo spomalené zložitost'ou veci alebo správaním účastníka konania, potom štát objektívne zodpovedá za vzniknuté prietahy v konaní.

Nie všetky priet’ahy vzniknuté v konaní je možné automaticky subsumovat' pod negatívne a porušujúce čl. 6 ods. 1 Dohovoru. Príkladom môže byt' oneskorenie konania spojené s pokusom o mimosúdne urovnanie sporu. ${ }^{39}$ Európsky súd pre ludské práva vo svoje rozhodovacej činnosti pripomína, že iba tie priet’ahy, ktoré možno pričítat' štátu, môžu byt' dôvodom pre prijatie záveru o nesplnení požiadavky primeranosti dížky konania.

Posledné kritérium, ktoré je posudzované pri hodnotení primeranosti dížky konania, je význam konania pre účastníkov. Uvedené kritérium sa objavuje predovšetkým v novšej rozhodovacej činnosti Európskeho súdu pre l'udské práva, ktoré preberajú vnútroštátne súdy zmluvných štátov. Európsky súd pre l’udské práva konštantne judikuje, že svojou povahou si vyžadujú rýchle prerokovanie veci, vzhl’adom na význam konania pre účastníkov konania, predovšetkým spory týkajúce sa osobného stavu a svojprávnosti niektorého z účastníkov konania, väzobné veci, prípady zverenia maloletých do osobnej starostlivosti niektorého z rodičov alebo inej osoby či pracovnoprávne spory.

Podobne ako v prípade všetkých práv zaručených Dohovorom, v prípade práva na prerokovanie veci v primeranej lehote, ide o medzinárodnú zodpovednost' štátu ako celku. Súd preto neskúma, ktorá zložka štátnej moci je za priet’ahy v konaní zod-

38 DRGONEC, J. Ústava Slovenskej republiky - Velký komentár. Teória a prax. Bratislava : C. H. Beck, 2015. s. 925.

39 SVÁK, J. Ochrana l’udských práv (z pohladu judikatúry a doktríny štrasburských orgánov ochrany práv). II. rozšírené vydanie. Bratislava : Eurokódex, 2006. s. 564. 
povedná. ${ }^{40}$ Vo veci Finger proti Bulharsku ${ }^{41}$ Európsky súd pre l’udské práva dodal, že konštatovanie porušenia práva na prerokovanie veci v primeranej lehote nutne neznamená, že to musia byt' práve a len súdne orgány, ktoré pochybili. Inak povedané, štát bude zodpovedat' za priet'ahy v konaní vždy, a to bez ohl'adu na to, aký reprezentant orgánu verejnej moci priet’ahy v konaní spôsobil či toleroval a neodstránil.

Je to práve činnost' iných orgánov, ktorá môže byt' príkladom aj pre rozhodovanie súdnych autorít. Dôvodom je skutočnost', že najmä procesné predpisy správneho práva či daňového práva spájajú s konaním orgánov a vydaním meritórneho rozhodnutia konkrétne lehoty, márne uplynutie ktorých znamená nezákonný postup orgánu spočívajúci v jeho nečinnosti. Napríklad podl’a $\S 49$ zákona č. 71/1967 Zb. o správnom konaní (správny poriadok) v platnom znení platí, že správny orgán rozhodne bud' bezodkladne, alebo do 30 dní od začatia konania a v obzvlášt' zložitých prípadoch maximálne do 60 dní. Ak nemožno vzhl'adom na povahu veci rozhodnút' ani v tejto 60 dňovej lehote, môže ju primerane predížit' odvolací orgán.

Presné stanovenie dížky súdneho konania na všetky súdne konania, alebo podl’a jednotlivých druhov súdnych konaní však nie je úplne právne správne. Dôvodom je osobitost' každého súdneho konania, ktorá je daná individualitou účastníkov súdneho konania ako aj skutočnosłami a skutkovým stavom, ktoré sú vlastné len prejednávanému prípadu.

Ako právne akceptovatel'né riešenie sa javí účinné využívanie sudcovskej koncentrácie konania ${ }^{42}$ a zavedenie odporúčaných procesných lehôt, v rámci ktorých má byt' vydané meritórne súdne rozhodnutie na úrovni práve konajúceho súdu. Sledovanie týchto lehôt a dôvodné predíženie lehoty na rozhodnutie by spočívalo v novovytvorenej právomoci súdu vyššej inštancie.

Autorka článku súčasne zastáva právny názor, že len stanovenie akejsi konečnej a odporúčanej doby vydania meritórneho rozhodnutia by nebolo postačujúcou legislatívnou zmenou, pretože by sa tak vytváral priestor pre „zákonné“ odôvodnenie nečinnosti súdu, a síce $\mathrm{v}$ tom, že v rámci uvedenej lehoty súd nestihol, resp. nebolo možné vykonat' procesné úkony. Pre zabezpečenie rýchlosti konania je preto potrebné aj legislatívne určenie lehoty na vykonanie procesných úkonov, ktoré sa spájajú so súdnym konaním, kedy jednotlivé lehoty by začínali plynút' odo dňa začatia súdneho konania.

Stanovenie odporúčaných procesných lehôt je dôvodné aj vzhl'adom na skutočnost', že pre účinné uplatňovanie práv sa aj od subjektov práva očakáva, že tieto práva budú uplatňovat' v lehotách stanovených právnymi predpismi. Príkladom je lehota dvoch mesiacov od oznámenia rozhodnutia, resp. opatrenia orgánu verejnej správy na podanie správnej žaloby podl'a $\S 181$ ods. 1 zákona č. 162/2015 Z. z. Správny súdny poriadok v platnom znení. Márne uplynutie lehoty pre subjekt práva vytvára prekážku domáhat' sa súdnej ochrany.

Naplnenie návrhu de lege ferenda si okrem precizácie právnej úpravy vyžaduje navýšenie personálneho zabezpečenia súdov, tak, aby priebežné sledovanie dodržia-

40 KMEC, J. a kol. Evropská úmluva o lidských právech. Komentár̆. 1. vydání. Praha : C. H. Beck, 2012. s. 710.

41 Rozhodnutie Európskeho súdu pre l’udské práva vo veci Finger vs. Bulharsko no. 37346/05, zo dňa 10.05.2011.

42 K tomu pozri: ŠTEVČEK, M. a kol. Civilný sporový poriadok. Komentár. Praha : C. H. Beck, 2016. s. 578-581; SVOBODA, K. Řizení v prvním stupni : civilní proces z pohledu účastníka. Praha : C.H.Beck, 2019. s. 499-516. 
vania odporúčaných procesných lehôt bolo vôbec možné uskutočňovat', pretože konštatovanie nedodržania lehôt len v prípadnom odvolacom či dovolacom konaní nie je z hladiska času účinným nástrojom, ako zrýchlit' a zefektívnit' súdne konanie.

Druhou podmienkou je určenie procesných lehôt na vykonanie procesných úkonov ako aj na vydanie meritórneho rozhodnutia podl’a prípadov aplikačnej praxe, tak, aby lehoty neboli nesplnitel’né a pre orgány súdnej moci šikanózne. Lehoty na konanie a rozhodnutie musia zodpovedat' priemeru aplikačnej praxe, a to $z$ dôvodu, že nielen príliš pomalé, ale aj rýchle súdne konanie môže znamenat porušenie práva na spravodlivý proces, kedy nebudú vykonané či zohl'adnené všetky skutočnosti, ktoré sú pre rozhodnutie dôležité a podstatné.

Pre účinné odstraňovanie priet’ahov v konaní, spôsobených najmä úmyselným konaním účastníkov súdneho konania ${ }^{43}$ bude nutné, aby boli vo väčšej miere uplatňované sankčné prostriedky majúce represívny charakter voči „,porušovatel'om“. Ak by súd ostal pasívny a nevyužil by všetky zákonom dovolené spôsoby voči takto konajúcemu účastníkovi konania, nekonanie by v konečnom dôsledku bolo pričítané na t’archu súdu a v prípade náhrady škody spôsobenej priet’ahmi v konaní štátu. Súčasne, sankčné prostriedky a ich „medializovanie“ budú mat aj preventívny a ochranný vplyv na ostatných účastníkov iných súdnych konaní.

Pokial' ide o zmieňovanú medializáciu, táto sa musí vykladat' vo význame informovanosti verejnosti o uplatňovaných sankciách a nie vo význame činnosti zástupcov masmediálnej komunikácie na súdnych pojednávaniach. Je síce pravdou, že masmédia v súčasnej dobe predstavujú nezastupitel'nú verejnost' na súdnych pojednávaniach a ich úloha je dôležitá. Nie je však správne a dokonca v niektorých konaniach, napríklad rodinnoprávnych, takmer vôbec prípustné, aby konanie alebo vyhlásenie súdneho rozhodnutia sledovali média. ${ }^{44}$

Ak majú byt' konania orgánov verejnej moci skutočne účinné a spravodlivé je potrebné pokúsit' sa o zákonné vymedzenie procesných lehôt, $\mathrm{v}$ rámci ktorých má dôjst' $\mathrm{k}$ vydaniu meritórneho súdneho rozhodnutia a to aspoň na súde prvého stupňa. Uvedená úvaha de lege ferenda by mohla byt' primárne obsiahnutá najmä v konaniach, $\mathrm{v}$ ktorých hrá čas v neprospech subjektu práva. V prípade súkromného práva by mohlo íst' napríklad o oblasti ochrany zdravia, dobrého mena a povesti, nárokov z pracovnoprávnych sporov či úpravy vzt’ahov medzi rodičmi a det'mi. Pokial' ide o verejné právo, osobitne dôležité sú trestné konania. Ak by však aj nedošlo k spresneniu právnej úpravy je potrebné, aby najmä orgány súdnej moci boli sami garantmi rýchlosti konania, najmä v tých prípadoch, ktoré už zo základných skutočností prípadu neznesú odklad.

\section{Záver}

Požiadavka prejednania veci v primeranej lehote vyplýva zo všeobecného pravidla „spravodlivost' zmeškaná, spravodlivost' odopretá“. V zásade nie je možné vylúčit', že vo výnimočných prípadoch môže byt' prehnané odd'al'ovanie rozhodnutia súdu

43 Rozhodnutie Európskeho súdu pre l’udské práva vo veci Tsikakis vs. Nemecko no. 1521/06, zo dňa 11.02.2011.

$44 \mathrm{~K}$ úlohe médií a rozhodovacej činnosti súdov pozri: ROZEHNAL, A. Stratégie civilního procesu. Plzeň : Aleš Čeněk, 2016. s. 228-230. 
považované za zásah do práva na prístup $\mathrm{k}$ súdu, resp. za odopretie spravodlivosti. ${ }^{45}$

Nečinnost' orgánu súdnej moci a z nej vyplývajúci záver o priet’ahoch v konaní môže byt' síce len dočasným odopieraním spravodlivosti účastníkovi konania, avšak v konečnom dôsledku môže mat' voči účastníkovi konania ešte závažnejší zásah, a to zmarit' účastníkovi konania uplatňovanie subjektívnych práv, najmä v súvislosti s konaním, v ktorom sa účastník konania domáha ochrany svojich ohrozovaných alebo porušovaných subjektívnych práv. Typickým príkladom môže byt' situácia, kedy uplynutím dlhšieho času môžu počas súdneho sporu zomriet ${ }^{46}$ niektorí svedkovia alebo ich zdravotný stav sa môže natol'ko zhoršit', že ich výsluch ${ }^{47} \mathrm{v}$ konaní už neprinesie želaný výsledok pre účastníka konania, aký by bol, ak by súd vykonal dokazovanie „bez zbytočných priet'ahov“. Rýchlost' konania a nevyhnutnost' konat' s náležitou starostlivost'ou sú osobitne dôležité aj v prípade tzv. statusových konanít8 a v konaniach, v ktorých vystupuje rodinnoprávny prvok, ${ }^{49}$ ako je napríklad úprava výkonu rodičovských práv rodičom $\mathrm{k}$ det’om na čas po rozvode manželstva.

Je preto osobitne dôležité, aby konania a nielen súdne, skončili vydaním meritórneho rozhodnutia $v$ čo najkratšom čase od ich začatia. Avšak stanovenie akejkol'vek presnej dížky súdneho konania by bolo právne neakceptovatel'né, a to z dôvodu potreby vnímat' osobitosti každého prípadu. Uprednostnenie požiadavky rýchlosti konania pred zohl'adnením všetkých skutočností dôležitých pre rozhodnutie by malo za následok ešte väčšie porušenie už tak porušovaných alebo ohrozovaných práv. Navrhované stanovenie procesných lehôt na rozhodnutie musí preto vychádzat' z priemeru trvania prípadov aplikačnej praxe.

\section{Literatúra:}

- BRÖSTL, A. 2015. Na konci je súd. Bratislava : Kalligram, 2015. 230 s. ISBN 978-80-8101-908-1.

- BÜHRER, T. 2020. Das Menschenwürdekonzept der Europäischen Menschenrechtskonvention. Duncker \& Humblot : Berlin, 2020. 361 s. ISBN 978-3-428-15611-5.

- CIBULKA, L. 2001. Kontexty Ústavy SR a Listiny základných práv a slobôd. In Deset let Listiny základných prav a svobod v právním rádu České republiky a Slovenské republiky. Brno : Masarykova univerzita Brno, 2001. 246 s. ISBN 97880-2102-749-7.

- DRGONEC, J. 2015. Ústava Slovenskej republiky - Vel'ký komentár. Teória a prax. Bratislava : C. H. Beck, 2015. 1603 s. ISBN 978-80-89603-39-8.

45 KMEC, J. a kol. Evropská úmluva o lidských právech. Komentář. 1. vydání. Praha : C. H. Beck, 2012. s. 698.

$46 \mathrm{~K}$ tomu pozri: Rozhodnutie Európskeho súdu pre l’udské práva vo veci X. vs. Francúzsko no 18020/91, zo dňa 31.03.1992.

47 K tomu pozri: WENDLER, A. - HOFFMANN, H. Technik und Taktik der Befragung im Gerichtsverfahren. Urteile begründen, Urteile prüfen. Lüge und Irrtum aufdecken. Stuttgart : W. Kohlhammer GmgH, 2009. $156 \mathrm{~s}$.

48 K tomu pozri: SMYČKOVÁ, R. - FILO, M. Civilné mimosporové konanie. Konania v niektorých statusových veciach fyzických osôb. Bratislava : C. H. Beck, 2016. $156 \mathrm{~s}$.

49 Rozhodnutie Európskeho súdu pre l’udské práva vo veci Fabišik vs. Slovensko no. 51204/99, zo dňa 22.03.2005. 
- DWORKIN, R. 2001. Když se práva berou vážně. Praha : Oikoymenh, 2001. 456 s. 978-80-729-8022-2.

- HARRIS, D.J. a kol. 2014. Law of the European Convention on Human Rights. Third Edition. Oxford University Press, 2014. s. 442 ISBN 978-0-19-960639-9.

- HAASE, K. 2006. Die Anforderungen an ein faires Gerichtsverfahren auf europäischer Ebene. Driesen : Dr. H. H. Verlag, 2006. 511 s. ISBN 978-39-363-2861-5.

- HENZELIN. M. - RORDORF, H. 2014. When does the length of criminal proceedings become unreasonable according to the European Court of Human Rights? In: New Journal of European Criminal Law. [online]. 2014, Vol. 5, Issue 1, s.79-109. [cit. 2020-06-30]. Dostupné na internete: https://www.lalive.law/data/ publications/NJECL_05_01_0078.pdf

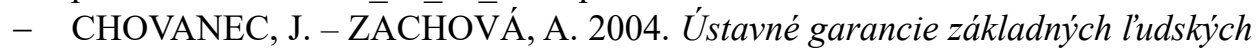
a občianskych práv a slobôd. Bratislava : Procom, s. r. o., 2004. s. 173. ISBN 8085717-10-7.

- CHRISTOFFERSEN, J. 2009. Fair balance: proportionality, subsidiarity and primarity in tje European Convention on Human Rights. International studies in human rights, v.99. Koninklijke Brill NV : Leiden, 2009. s. 467.ISBN 978-90-04-17028-5.

- KMEC, J. a kol. 2012. Evropská úmluva o lidských právech. Komentár. 1. vydání. Praha : C. H. Beck, 2012. 1660 s. ISBN 978-80-7400-365-3.

- KOENIG, M. 2005. Menschenrechte. Frankfurt : Campus Verlag GmbH, 2005. 168 s. ISBN 978-3593371863.

- MAĎAR, M. 2017. Predvídatel'nost' súdnych rozhodnutí ako súčast' práva na spravodlivý proces. In Banskobystrické dni práva : zborník z 2. ročníka medzinárodnej vedeckej konferencie na tému „Kvalita normotvornej a aplikačnej stránky zákonnosti ako determinant právneho štátu”, 23.-24. november 2016. Banská Bystrica : Vydavatel'stvo Univerzity Mateja Bela - Belianum, 2017. ISBN 978-80-557-1285-7. $419 \mathrm{~s}$.

- MARTIN, C. - RODRÍGEUZ-PINZÓN, D. - BROWN, B. 2015. Human Rights of Older People. Universal and Regional Legal Perspectives. Springer Science+Bussiness Media : Dordrecht, 2015. s. 199-200. ISBN 978-94-017-7184-9.

- ONDROVÁ, J. 2018. Postavenie Európskeho dohovoru o ochrane l'udských práv a základných slobôd v právnom poriadku Slovenskej republiky. In Notitiae Novae Facultatis Iuridicae Universitatis Matthiae Belii Neosolii. Banská Bystrica : Vydavatel'stvo Univerzity Mateja Bela - Belianum, 2018. ISBN 978-80-557-14226. s. 154-162.

- ONDROVÁ, J. 2018. Právo na spravodlivý proces v rozhodovacej činnosti Ústavného súdu Slovenskej republiky a Európskeho súdu pre l’udské práva. Banská Bystrica : Belianum, Vydavatel'stvo Univerzity Mateja Bela v Banskej Bystrici, 2018. 144 s. ISBN 978-80-557-1400-4.

- PROCHÁZKA, R. 2011. Lud a sudcovia v konštitučnej demokracii. Plzeň : Aleš Čenek, 2011. 139 s. ISBN 978-80-7380-328-5.

- PRUSÁK, J. 2001. Teória práva. Bratislava : Právnická fakulta UK, 2001. 308 s. ISBN 80-7160-146-2. 
- RENZIKOWSKI, J. 2004. Die EMRK im Privat-Straf- und Öffentlichen Recht, Grundlagen einer europäischen Rechtskultur. Zürich : Schulthess Verlag, 2004. 255 s. ISBN 978-3-7255-4808-8.

- ROZEHNAL, A. 2016. Stratégie civilního procesu. Plzeň : Aleš Čeněk, 2016. 244 s. ISBN 978-80-7380-635-4.

- SMYČKOVÁ, R. - FILO, M. 2016. Civilné mimosporové konanie. Konania v niektorých statusových veciach fyzických osôb. Bratislava : C. H. Beck, 2016. 156 s. ISBN: 978-80-89603-48-0.

- SMYČKOVÁ, R. a kol. 2017. Civilnýmimosporový poriadok. Komentár. 1. vydanie. Bratislava : C. H. Beck, 2017. 1112 s. ISBN: 978-80-89603-54-1.

- SVÁK, J. a kol. 2004. Advokát pred európskymi súdmi. Bratislava : Poradca podnikatel'a, spol. s. r. o., 2004. 416 s. ISBN 80-8893-130-4.

- SVÁK, J. 1997. Nezávislost' súdnictva a zodpovednost' sudcov. In Právny obzor. ISSN 0032-6984, 1997, roč. 80, č. 5, s. 487-498..

- SVÁK, J. 2006. Ochrana ludských práv (z pohladu judikatúry a doktríny štrasburských orgánov ochrany práv). II. rozšírené vydanie. Bratislava : Eurokódex, 2006. 1116 s. ISBN 80-88931-51-7.

- SVÁK, J. 2013. Právo na súdnu a inú právnu ochranu. In: SVÁK, J.- CIBULKA, L.: Ústavné právo Slovenskej republiky, Osobitná čast'. 5. Aktualizované vydanie. Bratislava: Eurokódex s.r.o. a Paneurópska vysoká škola, 2013, s. 651, ISBN: 9678-80-8155-006-5.

- SVOBODA, K. 2019. Ľizení v prvním stupni : civilní proces z pohledu účastníka. Praha : C.H.Beck, 2019. 682 s. ISBN 978-80-7400-733-0.

- ŠTEVČEK, M. a kol. 2016. Civilný sporový poriadok. Komentár. Praha : C. H. Beck, 2016, 1540 s. ISBN: 978-80-7400-629-6.

- ŠTEVČEK, M. - PAVELKOVÁ, B. - CIRÁK, J. 2008. Rodinné právo. Šamorín : Heuréka, 2008. 216 s. ISBN 978-80-89122-47-9.

- VORLÄNDER, H. 2009. Die Verfassung. Idee und Geschichte. München : C. H. BECK, 2009. 128 s. ISBN 978-34-0643-316-0.

- WAGNEROVÁ, E. a kol. 2012. Listina základnich práv a svobod. Komentářr. Praha : Wolters Kluwer ČR, a. s. 2012. 906 s. ISBN: 978-80-7357-750-6.

- WENDLER, A. - HOFFMANN, H. 2009. Technik und Taktik der Befragung im Gerichtsverfahren. Urteile begründen, Urteile prüfen. Lüge und Irrtum aufdecken. Stuttgart : W. Kohlhammer GmgH. 2009. 156 s. ISBN 978-3-17-020446-1.

\section{Právne predpisy}

- zákon č. 71/1967 Zb. o správnom konaní (správny poriadok) v platnom znení.

- zákon č. 460/1992 Zb. Ústava Slovenskej republiky v platnom znení.

- zákon č. 385/2000 Z. z. o sudcoch a prísediacich a o zmene a doplnení niektorých zákonov v platnom znení.

- zákon č. 301/2005 Z. z. Trestný poriadok v platnom znení.

- zákon č. 160/2015 Z. z. Civilného sporového poriadku v platnom znení.

- zákon č. 161/2015 Z. z. Civilného mimosporového poriadku v platnom znení.

- zákon č. 162/2015 Z. z. Správny súdny poriadok v platnom znení. 
- zákon č. 314/2018 Z. z. o Ústavnom súde Slovenskej republiky a o zmene a doplnení niektorých zákonov v platnom znení.

\section{Súdne rozhodnutia}

- Rozhodnutie Európskeho súdu pre l’udské práva vo veci Deweer vs. Belgicko no. 6903/75, zo dňa 27.02.1980.

- Rozhodnutie Európskeho súdu pre ludské práva vo veci Zimmerman a Steiner vs. Švajčiarsko no. 8737/79, zo dňa 13.07.1983.

- Rozhodnutie Európskeho súdu pre l'udské práva vo veci X. vs. Francúzsko no 18020/91, zo dňa 31.03.1992.

- Rozhodnutie Európskeho súdu pre l'udské práva vo veci Niederböster vs. Nemecko no. 39547/98, zo dňa 27.02.2003.

- Rozhodnutie Európskeho súdu pre l'udské práva vo veci Schmidtová vs. Česká republika no. 48568/99, zo dňa 22.07.2003.

- Rozhodnutie Európskeho súdu pre l’udské práva vo veci Fabišik vs. Slovensko no. 51204/99, zo dňa 22.03.2005.

- Rozhodnutie Európskeho súdu pre l’udské práva vo veci Nemeth vs. Česká republika no. 35888/02, zo dňa 20.09.2005.

- Rozhodnutie Európskeho súdu pre l’udské práva vo veci Sürmeli vs. Nemecko no. 75529/01, zo dňa 08.06.2006.

- Rozhodnutie Európskeho súdu pre l'udské práva vo veci Tsikakis vs. Nemecko no. $1521 / 06$, zo dňa 11.02.2011.

- Rozhodnutie Európskeho súdu pre l’udské práva vo veci Finger vs. Bulharsko no. 37346/05, zo dňa 10.05.2011.

- Rozhodnutie Európskeho súdu pre l'udské práva vo veci Ersin Ceyhan vs. Turecko no. 2013/695, zo dňa 09.01.2014.

- Rozhodnutie Európskeho súdu pre l'udské práva vo veci Lupeni Greek Catholic Parish and Others vs. Rumunsko no. 76943/11, zo dňa 29.11.2016.

- Nález Ústavného súdu Slovenskej republiky sp. zn. II. ÚS 26/95 zo dňa 25.10.1995.

- Nález Ústavného súdu Slovenskej republiky sp. zn. II. ÚS 64/99 zo dňa 13.07.1999.

- Nález Ústavného súdu Slovenskej republiky sp. zn. II. ÚS 8/01 zo dňa 18.06.2001.

- Nález Ústavného súdu Slovenskej republiky sp. zn. IV. ÚS 471/2012 zo dňa 07.05.2013.

- Nález Ústavného súdu Slovenskej republiky sp. zn. I. ÚS 697/2013 zo dňa 19.03.2014.

- Nález Ústavného súdu Slovenskej republiky sp. zn. II. ÚS 498/2013 zo dňa 11.06.2014.

- Nález Ústavného súdu Slovenskej republiky sp. zn. I. ÚS 688/2014 zo dňa 04.02.2015.

- Nález Ústavného súdu Slovenskej republiky sp. zn. II. ÚS 510/2014 zo dňa 11.06.2015.

- Nález Ústavného súdu Slovenskej republiky sp. zn. III. ÚS 139/2015 zo dňa 16.06.2015.

- Nález Ústavného súdu Slovenskej republiky sp. zn. II. ÚS 862/2015 zo dňa 17.03.2016.

- Nález Ústavného súdu Slovenskej republiky sp. zn. I. ÚS 65/2016 zo dňa 08.06.2016.

- Nález Ústavného súdu Slovenskej republiky sp. zn. III. ÚS 47/2017 zo dňa 25.04.2017. 
- Nález Ústavného súdu Slovenskej republiky sp. zn. II. ÚS 268/2019 zo dňa 23.01.2020.

- Uznesenie Najvyššieho súdu Slovenskej republiky sp. zn. 1 Cdo 107/2009 zo dňa 28.07.2010.

- Uznesenie Ústavného súdu Slovenskej republiky sp. zn. II. ÚS 534/2011 zo dňa 23.11.2011.

- Uznesenie Ústavného súdu Slovenskej republiky sp. zn. II. ÚS 650/2015 zo dňa 06.10.2015.

Summary: Procedural Deadlines as Means of Removing Delays in Proceedings Within the Context of Law Regarding the Right to Just Trial

Finally, we can conclude that the constitution creator qualifies the demand addressed to the judicial power bodies to act in congruence with the Constitution as the highest legal power to follow strictly not only the legal order but at the same time to act as fast as possible respecting thus the so-called reasonable time without any delays. The most effective elimination of the court delays, which appear not only in the part of the judicial power bodies, but quite often caused by the court participants' behavior. This reality wants to apply more the so-called sanction-mechanism that would be not only of a repressive character but likewise of the preventive and protection characters and in this way having an influence at all other court action participants.

JUDr. Júlia Ondrová, PhD.

Univerzita Mateja Bela v Banskej Bystrici Právnická fakulta, Katedra ústavného práva a teórie práva

Komenského 20 97401 Banská Bystrica Slovenská republika julia.ondrova@umb.sk 